\title{
NOTE
}

\section{FUSARIC ACID, A HYPOTENSIVE AGENT PRODUCED BY FUNGI}

\author{
Hiroyoshi Hidaka*, Toshiharu Nagatsu \\ and KazUmi Takeya \\ Department of Biochemistry and Department \\ of Pharmacology, School of Dentistry, \\ Aichi-Gakuin University, \\ Nagoya, Japan \\ Tomio Takeuchi, Hiroyuki Suda, \\ Katsuhisa Kojiri, Meiki Matsuzaki**, \\ and Hamao Umezawa \\ Institute of Microbial Chemistry \\ Shinagawa-ku, Tokyo, Japan
}

(Received for publication March 13, 1969)

An active compound was found by systematic screening of fungus products inhibiting dopamine- $\beta$-hydroxylase and identified as fusaric acid (5-butylpicolinic acid) which had been known as an antibiotic exhibiting weak antimicrobial properties.

Dopamine- $\beta$-hydroxylase is one of enzymes involved in biosynthesis of norepinephrine and some of its inhibitors are thought to have hypotensive activity. The enzyme was prepared from the medulla of beef adrenals, and the culture filtrates of fungi isolated from nature were screened for inhibition of this enzyme. The method of testing has been reported by Nagatsu et al. ${ }^{1)}$ In this method, tyramine is employed as the substrate and the reaction product (octopamine) is determined spectrophotometrically after being oxidized to $p$-hydroxybenzaldehyde.

In the course of screening, a culture filtrate of a fungus was found to contain a compound inhibiting dopamine- $\beta$-hydroxylase. This fungus was cultured in shake flasks in a medium containing $3.5 \%$ glucose, $1.0 \%$ corn starch, $2.0 \%$ soybean meal, $0.5 \%$ peptone, $0.5 \%$ meat extract, $0.2 \% \mathrm{NaCl}$, $0.05 \% \quad \mathrm{KH}_{2} \mathrm{PO}_{4}$ and $0.05 \% \quad \mathrm{MgSO}_{4} \cdot 7 \mathrm{H}_{2} \mathrm{O}$ ( $\mathrm{pH} \quad 6.0 \sim 6.2)$ with $0.005 \%$ silicone resin added as an antifoam agent. The active metabolite was produced between $2 \sim 7$ days of the shake culture and after 4 days of aerated fermentation in a fermentor of 4,000 liter volume. The active compound in the culture filtrate was adsorbed on active carbon and eluted with $0.05 \mathrm{~N} \mathrm{HCl}$ methanol. Concentration of the eluate in vacuo gave precipitate of the active compound.which was crystallized from hot methanol. Calcd. for $\mathrm{C}_{10} \mathrm{H}_{13} \mathrm{NO}_{2} \cdot \frac{1}{2} \mathrm{Ca}$ : C 60.28, $\mathrm{H}$ 6.58, N 7.03, O 16.06, Ca 10.04; found: C 57.79, H 6.46, $\mathrm{N} 6.81$, O 15.65, Ca 11.20. The content of calcium was determined by atomic absorption spectrum. The treatment of the active compound by cation-exchange resin chromatography (XE-64, $\mathrm{H}$ form) using acetone methylethylketone $-0.12 \mathrm{~N} \mathrm{HCl}(1: 2: 6)$ gave the hydrochloride which was crystallized from hot butyl acetate. Calcd. for $\mathrm{C}_{10} \mathrm{H}_{13} \mathrm{NO}_{2}$. $\mathrm{HCl}: \mathrm{C} 55.65, \mathrm{H} 6.54, \mathrm{~N} 6.50, \mathrm{O} 14.80, \mathrm{Cl}$ 16.44 ; found: C $57.90, \mathrm{H} 6.81, \mathrm{~N} 6.67, \mathrm{O}$ 14.50, Cl 15.50.

Extraction of an aqueous solution of the hydrochloride with butyl acetate and the subsequent evaporation gave the free acid of the active compound which was then crystallized from hot carbon tetrachloride: m. p. $102.5 \sim 103.5^{\circ} \mathrm{C}$; calcd. for $\mathrm{C}_{10} \mathrm{H}_{13} \mathrm{NO}_{2}$ : C 67.02, H 7.31, N 7.82, O 17.86; found: C 66.46, H 7.29, N 7.95, O 17.08. The structure of 5-butylpicolinic acid was suggested by n.m.r. spectrum $\left(60 \mathrm{MHz}\right.$ in $\mathrm{CDCl}_{3}$, TMS as the internal reference) as follows :<smiles>CCCCc1ccccc1</smiles>

(a) $0.8 \sim 1.2 \mathrm{ppm}(m)$

(b) $1.2 \sim 2.0 \mathrm{ppm}(m)$

(c) $2.80 \mathrm{ppm}(t) \quad \mathrm{J} \quad 7.5 \mathrm{~Hz}$

(d) $7.85 \mathrm{ppm}(d-d)$ Jde $8 \mathrm{~Hz}$

(e) $8.27 \mathrm{ppm}(d-d)$ Jdf $2 \mathrm{~Hz}$

(f) $8.77 \mathrm{ppm}(d-d)$ Jef $<1 \quad \mathrm{~Hz}$

(g) $13.17 \mathrm{ppm}(s)$

$\mathrm{J}$ : coupling constant, $m$ : multiplet, $t$ : triplet, $d-d$ : double-doublets, $s$ : singlet.

* Postdoctral visiting fellow in Aichi-Gakuin University, School of Dentistry,

Present address: Institute of Biochemistry, Faculty of Medicine, University of Nagoya, Nagoya, Japan.

** Present address: Banyu Pharmaceutical Co., Ltd., Meguro Institute, Tokyo, Japan. 
Table 1. Effect of fusaric acid on the blood pressure of the rabbits under urethane anesthesia.

\begin{tabular}{|c|c|c|c|c|c|c|c|c|c|c|c|c|c|c|}
\hline \multirow{2}{*}{$\begin{array}{c}\text { Dose } \\
\mathrm{mg} / \mathrm{kg}\end{array}$} & \multirow{2}{*}{ Route } & \multirow{2}{*}{$\begin{array}{l}\text { Body } \\
\text { weight } \\
\text { kg }\end{array}$} & & \multicolumn{11}{|c|}{ Time after administration } \\
\hline & & & & $\begin{array}{c}0 \\
\min .\end{array}$ & $\begin{array}{c}5 \\
\min \\
\end{array}$ & $\begin{array}{c}10 \\
\min .\end{array}$ & $\begin{array}{c}15 \\
\min . \\
\end{array}$ & $\begin{array}{c}30 \\
\min \end{array}$ & $\begin{array}{c}1 \\
\mathrm{hr}\end{array}$ & $\begin{array}{c}2 \\
\mathrm{hrs} .\end{array}$ & $\begin{array}{c}3 \\
\text { hrs. }\end{array}$ & $\begin{array}{c}4 \\
\text { hrs. }\end{array}$ & $\begin{array}{c}6 \\
\text { hrs. } \\
\text { hrs. }\end{array}$ & $\begin{array}{c}24 \\
\text { hrs. }\end{array}$ \\
\hline \multirow{2}{*}{50} & \multirow{2}{*}{ Oral } & \multirow{2}{*}{2.0} & $\begin{array}{c}\text { Blood pressure, } \\
\mathrm{mmHg}\end{array}$ & 93 & 83 & 77 & 73 & 63 & 65 & 70 & 69 & 72 & 74 & 50 \\
\hline & & & Depression \% & & 11 & 17 & 22 & 32 & 30 & 25 & 26 & 23 & 20 & 46 \\
\hline \multirow[t]{2}{*}{25} & \multirow[t]{2}{*}{ Oral } & \multirow[t]{2}{*}{3.2} & $\begin{array}{l}\text { Blood pressure, } \\
\text { mmHg }\end{array}$ & 99 & 97 & 95 & 96 & 94 & 96 & 94 & & 101 & 105 & 101 \\
\hline & & & Depression \% & & 2 & 4 & 3 & 5 & 3 & 5 & & -2 & -6 & -2 \\
\hline
\end{tabular}

Identity with fusaric acid was proven by comparison with authentic samples prepared by fermentation of Fusarium oxysporum, a known producer of fusaric acid, supplied by Prof. S. TAMURA and assistant Prof. N. TAKAhashi, Department of Agricultural Chemistry, University of Tokyo or prepared by chemical synthesis. The strain of the fungus which produced the fusaric acid was classified as Fusarium sp. by Prof. Y. SASAKI, Department of Agricultural Chemistry, University of Hokkaido.

When $20 \mathrm{mg} / \mathrm{kg}$ of fusaric acid was injected intraperitoneally into rabbits, rats, cats or dogs, significant decreases of blood pressure were observed from about $30 \mathrm{mi}$ nutes to 6 hours after the injection. When the dose was raised to $50 \mathrm{mg} / \mathrm{kg}$, the blood pressure decrease was greater and the lowered pressure was maintained for more than 24 hours. An example of experiments indicating the hypotensive effect on rabbits is shown in Table 1. Oral administration of $30 \mathrm{mg} / \mathrm{kg}$ of this compound showed almost the same effect as intraperitoneal injection of $20 \mathrm{mg} / \mathrm{kg}$. The hypotensive effect was also observed in dogs as is shown in Fig. 1. The $L_{50}$ of fusaric acid for mice was 100 $\mathrm{mg} / \mathrm{kg}$ by intravenous injection and $80 \mathrm{mg} / \mathrm{kg}$ by intraperitoneal injection. Daily intramuscular injection or oral administration of $40 \mathrm{mg} / \mathrm{kg}, 20 \mathrm{mg} / \mathrm{kg}$ or $10 \mathrm{mg} / \mathrm{kg}$ caused no toxic sings in dogs except vomiting in some of the dogs receiving oral administration. The death caused by the lethal dose was thought to be due to its hypotensive effect, and not to other factors. The calcium salt of fusaric acid showed the same effect.
Fig. 1. Effect of fusaric acid $(40 \mathrm{mg} / \mathrm{kg}$, i. p.) on the blood pressure of the dog (male, $10 \mathrm{~kg}$ ) under urethane anesthesia.

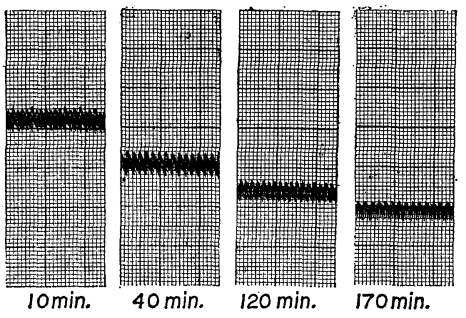

The $L D_{50}$ of the calcium salt for mice was $125 \mathrm{mg} / \mathrm{kg}$ both by the intraperitoneal and by the intramuscular routes. Oral administration of the calcium salt produced the same effect as the acid but dogs were able to tolerate the calcium salt without vomiting.

After intraperitoneal injection of 100 $\mathrm{mg} / \mathrm{kg}$ fusaric acid to rats, there was a marked decrease of norepinephrine in the heart $(0.6 \mu \mathrm{g} / \mathrm{g}$ tissue before injection, $0.2 \sim$ $0.3 \mu \mathrm{g} / \mathrm{g}$ during 3 9 hours after the injection) and almost complete recovery after 12 hours. The decrease of norepinephrine in the brain was slight $(0.22 \mu \mathrm{g} / \mathrm{g}$ before injection, $0.11 \mu \mathrm{g} / \mathrm{g}$ after 3 hours, $0.17 \mu \mathrm{g} / \mathrm{g}$ after 6 hours, $0.19 \mu \mathrm{g} / \mathrm{g}$ after 9 hours, $0.21 \mu \mathrm{g} / \mathrm{g}$ after 12 hours). The decrease was also slight in the spleen $(0.32 \mu \mathrm{g} / \mathrm{g}$ before injection, $0.25 \mu \mathrm{g} / \mathrm{g}$ after 3 hours, $0.31 \mu \mathrm{g} / \mathrm{g}$ after 6 hours). The decrease of the sum of norepinephrine and epinephrine in the adrenal glands was marked $(0.68 \mathrm{mg} / \mathrm{g}$ before injection, $0.18 \mathrm{mg} / \mathrm{g}$ after 3 hours, $0.16 \mathrm{mg} / \mathrm{g}$ after 9 hours and $0.5 \mathrm{mg} / \mathrm{g}$ after 24 hours). Details of these experiments will be published in other paper. The decrease of norepinephrine in the heart and adrenal is thought to be due to inhibition of dopamine$\beta$-hydroxylase by the fusaric acid and the decrease of norepinephrine in angiovascular 
system is thought to be the cause of the hypotensive effect.

\section{Acknowledgement}

The author express their deep thanks to Prof. Y. SASAKI, Department of Agricultural Chemistry, University of Hokkaido for his rapid classification of the fungus, to Dr. N. TakaHashi for his kindness in supplying the Fusarium oxysporum culture, a known producer of fusaric acid, and to Banyu Pharmaceutical Co., Ltd., for preparation of authentic fusaric acid.

\section{References}

1) KuzuYa, H. \& T. Nagatsu: A simple assay of dopamine $\beta$-hydroxylase activity in the homogenate of the adrenal medulla. Enzymologia $36: 31 \sim 38,1969$. 